\title{
Naar een informatiesysteem onderwijs - arbeidsmarkt. Onderzoekprogramma 1987/88
}

Citation for published version (APA):

Researchcentrum voor Onderwijs en Arbeidsmarkt, ROA. (1987). Naar een informatiesysteem onderwijs arbeidsmarkt. Onderzoekprogramma 1987/88. Researchcentrum voor Onderwijs en Arbeidsmarkt, Faculteit der Economische Wetenschappen. ROA Reports No. 002

https://doi.org/10.26481/umarep.1987002

Document status and date:

Published: 01/01/1987

DOI:

10.26481/umarep.1987002

Document Version:

Publisher's PDF, also known as Version of record

\section{Please check the document version of this publication:}

- A submitted manuscript is the version of the article upon submission and before peer-review. There can be important differences between the submitted version and the official published version of record.

People interested in the research are advised to contact the author for the final version of the publication, or visit the DOI to the publisher's website.

- The final author version and the galley proof are versions of the publication after peer review.

- The final published version features the final layout of the paper including the volume, issue and page numbers.

Link to publication

\footnotetext{
General rights rights.

- You may freely distribute the URL identifying the publication in the public portal. please follow below link for the End User Agreement:

www.umlib.nl/taverne-license

Take down policy

If you believe that this document breaches copyright please contact us at:

repository@maastrichtuniversity.nl

providing details and we will investigate your claim.
}

Copyright and moral rights for the publications made accessible in the public portal are retained by the authors and/or other copyright owners and it is a condition of accessing publications that users recognise and abide by the legal requirements associated with these

- Users may download and print one copy of any publication from the public portal for the purpose of private study or research.

- You may not further distribute the material or use it for any profit-making activity or commercial gain

If the publication is distributed under the terms of Article $25 \mathrm{fa}$ of the Dutch Copyright Act, indicated by the "Taverne" license above, 
NAAR EEN INFORMATIESYSTEEM ONDERWIJS - ARBEIDSMARKT

- onderzoekprogramma 1987/88 -

$\mathrm{ROA}-\mathrm{R}-1987 / 2$

RESEARCHCENTRUM VOOR ONDERWIJS EN ARBEIDSMARKT

Faculteit der Economische Wetenschappen

Rijksuniversiteit Limburg

Maastricht, april 1987 
1. Inleiding 2

2. Arbeidsmarktgegevens voor school- en beroepskeuze

3. De relatie onderwijs- en arbeidsmarkt in schema

4. Een eenvoudig model van de werkgelegenheid naar beroep

5. Het onderzoekprogramma 
VOORWOORD

In de zomer van 1986 werd het Researchcentrum voor Onderwijs en Arbeidsmarkt (ROA) opgericht. De start van het centrum werd mogelijk gemaakt door een meerjarige onderzoeksopdracht van het Ministerie van Onderwijs en Wetenschappen. Over de voorgeschiedenis en de plannen van het ROA is een nota samengesteld: Het Researchcentrum voor Onderwijs en Arbeidsmarkt (ROA-R-1986/1). Deze nota is op aanvraag bij het centrum verkrijgbaar.

Er wordt getracht - naast de lopende opdracht van het Ministerie van Onderwijs en Wetenschappen - nieuwe onderzoeksopdrachten te verwerven, zodat het centrum zichzelf financieel in stand kan houden. Mogelijke thema's voor onderzoek worden in boven genoemde nota aangegeven.

De onderzoeksopdracht van het Ministerie van Onderwijs en Wetenschappen houdt in het ontwikkelen van een informatiesysteem waarmee de (toekomstige) ontwikkelingen op de arbeidsmarkt kunnen worden weergegeven en waarin de daarvan afgeleide eisen voor het onderwijs tot uitdrukking kunnen worden gebracht. Het te ontwikkelen systeem zou bruikbaar moeten zijn voor de studie- en beroepskeuzevoorlichting in het voortgezet- en het hoger onderwijs.

In de onderhavige nota wordt het programma van activiteiten ontwikkeld dat nodig is om bovengenoemd informatiesysteem te realiseren. Het programma heeft betrekking op de jaren 1987 en 1988 . Het is de bedoeling elk jaar een nieuwe versie uit te brengen. Wel wordt overwogen het te publiceren programma te verbreden tot alle activiteiten van het ROA, warin de ontwikkeling van het informatiesysteem onderwijs-arbeidsmarkt dan als afzonderlijk programma-onderdeel wordt onderscheiden.

Ter informatie is de huidige personele samenstelling van het ROA weergegeven in een bijlage bij deze nota.

prof. dr. J.A.M. Heijke, directeur 


\section{INLEIDING}

Het Ministerie van Onderwijs en Wetenschappen heeft aan de Faculteit der Economische Wetenschappen van de Rijksuniversiteit Limburg opdracht verleend om een informatiesysteem te ontwikkelen wa armee ontwikkelingen op de arbeidsmarkt kunnen worden weergegeven en waarin de daarvan af te leiden eisen voor het onderwijs tot uitdrukking kunnen worden gebracht. Binnen de Economische Faculteit is het Researchcentrum voor Onderwijs en Arbeidsmarkt (ROA) belast met de uitvoering van deze opdracht.

Bij de ontwikkeling van het informatiesysteem zullen enkele uitgangspunten in acht worden genomen. Het eerste uitgangspunt betreft dat het systeem informatie moet opleveren welke bruikbaar is voor de studie- en beroepskeuzevoorlichting ten behoeve van leerlingen en studenten in respectievelijk het voortgezet- en het hoger onderwijs. Dit sluit niet uit dat de verschafte informatie ook van nut kan zijn voor de beantwoording van andere vragen met betrekking tot de relatie onderwijs - arbeidsmarkt, dan die rond de school- en beroepskeuze. Hierbij kan worden gedacht aan het verbeteren van de afstemming van de capaciteiten van de onderwijsvoorzieningen op de arbeidsmarktperspectieven voor de op te leiden studenten en het zodanig structureren van het economisch potentieel dat meer profijt wordt getrokken van de investeringen in kennis en vaardigheden van de bevolking.

Het tweede uitgangspunt is dat de te verschaffen informatie van kwantitatieve aard moet zijn. Het gaat dus om het verschaffen van gegevens over de ontwikkeling van de werkgelegenheid in de verschillende delen van de arbeidsmarkt, de ontwikkeling van de onderscheiden categorieën van de beroepsbevolking, de doorstroming van leerlingen door de diverse delen van het onderwijs e.d. Het systeem zal dus (vooralsnog) geen kwalitatieve informatie, zoals de specifieke inhoud van de aangeboden banen of van het genoten onderwijs, behoeven op te leveren. 
Als derde uitgangspunt geldt dat optimaal profijt moet worden getrokken van reeds beschikbare kwantitatieve gegevens en van bestaande kennis om de ontbrekende gegevens beschikbaar te maken. Het informatiesysteem zal daarom naast het opzetten van een databank en het ontwikkelen c.q. koppelen van econometrische mode1len, de opbouw betekenen van een netwerk van contacten met instanties die een bijdrage kunnen leveren in de vorm van gegevens en know how.

Het vierde en laatste uitgangspunt betreft de duurzaamheid van het informatiesysteem. Het gaat niet om een eenmalige operatie om nieuwe prognoses op te stellen van toekomstige ontwikkelingen op de arbeidsmarkt en in het onderwijs, maar om de ontwikkeling van een duurzaam instrument dat de vereiste gegevens met regelmatige tussenpozen en op basis van actuele inzichten kan verschaffen.

Het informatiesysteem kan in principe op twee manieren worden ontwikkeld. De eerste manier is om het systeem te zien als een groot en veelzijdig bouwwerk dat steen voor steen wordt opgetrokken en dat pas voor gebruik gereed is als de laatste voorzieningen zijn aangebracht. Deze benadering heeft echter enkele nadelen. Pas na enkele jaren zal duidelijk worden wat men van het systeem mag verwachten ten aanzien van zowel de aard als de kwaliteit van de verschafte informatie. Inmiddels kunnen de prioriteiten zijn verlegd, of kan blijken dat een andere aanpak tot een kwalitatief beter resultaat zou leiden. Daarom lijkt het beter het systeem op een andere manier te ontwikkelen.

De tweede manier houdt in dat 1 angs twee 1 ijnen wordt gewerkt. De eerste lijn betreft het ontwikkelen van een voorlopig informatiesysteem, op basis van direkt beschikbare gegevens en op korte termijn te mobiliseren kennis. Dit zal in de praktijk neerkomen op:

1. een beperking tot slechts enkele variabelen waarover het systeem informatie moet verschaffen;

2. een globale categorisering van de statistische gegevens over 
deze variabelen;

3. de benutting van bestaande (officiële) gegevensbronnen;

4. het toepassen en koppelen van reeds beproefde modellen.

Het voorlopige systeem zal geleidelijk worden uitgebouwd en verbeterd op basis van de resultaten die bij het volgen van de tweede lijn worden bereikt. Deze tweede lijn houdt in het ontwikkelen en uitvoeren van een programma van activiteiten dat is gericht op:

1. het definitief bepalen van de a ard en de vorm van de via het systeem te verschaffen informatie;

2. het verbeteren van de werking van deelmodellen uit het systeem;

3. het evalueren van voorlopige uitkomsten;

4. het op zetten en bijhouden van een databank en het eventueel ontwikkelen van nieuwe databronnen;

5. het opzetten en onderhouden van een netwerk van contacten met andere instanties welke gegevens kunnen leveren die gĩntegreerd kunnen worden in het informatiesysteem;

6. het organiseren van bijeenkomsten wa ar bepaalde vraagstukken verbonden a an de ontwikkeling van het systeem worden besproken;

7. het opzetten van een programma van fundamenteel onderzoek waarvan de resultaten tot een verbeterde opzet en werking van het informatiesysteem kunnen leiden.

In deze nota zal de hierboven geschetste benadering verder worden uitgewerkt. Er zal geen volledige invulling worden gegeven voor de gehele looptijd van de onderzoeksopdracht van het Ministerie van Onderwijs en Wetenschappen ( 5 jaar). De onzekerheden over de wenselijkheden en mogelijkheden ten aanzien van het te ontwikkelen informatiesysteem hebben juist geleid tot de geschetste stapsgewijze aanpak, waarbij al snel voorlopige resultaten van een systeem als geheel kunnen worden gepresenteerd en beoordeeld, en waarbij de mede op basis hiervan uitgevoerde deelstudies steeds op hun betekenis voor deze "overall" resultaten kunnen worden beproefd. Deze nota heeft daarom een voorlopig karakter en 
kan a an de hand van nieuwe inzichten worden uitgewerkt en verbeterd.

De opzet van de nota is als volgt. Er zal eerst worden ingegaan op de arbeidsmarktgegevens, die van belang zijn voor het schoolen beroepskeuzeproces, warop het informatiesysteem zich zal richten. Daarna wordt het globale systeem geschetst dat op korte termijn zal worden ontwikkeld. Deze schets wordt voorafgegaan door een algemeen schema van de relatie onderwijs-arbeidsmarkt, dat als referentiekader kan dienen voor het globale arbeidsmarktinformatiesysteem. Tenslotte zal een aanzet worden gegeven voor een programma van toegepast en fundamenteel onderzoek dat nodig is om het globale systeem te ontwikkelen tot het beoogde arbeidsmarktinformatie genererende instrument. 


\section{ARBEIDSMARKTGEGEVENS VOOR SCHOOL- EN BEROEPSKEUZE}

Uit onderzoek onder VWO- en HAVO-abituriënten is gebleken dat arbeidsmarktperspectieven, zoals het verwachte toekomstige inkomen en de kansen op het vinden van werk, in beschouwing worden genomen bij de keuze voor het al dan niet deelnemen aan een vervolgopleiding ${ }^{1)}$. Het verschaffen van informatie over de toekomstige ontwikkelingen op de arbeidsmarkt zou dan in een behoefte kunnen voorzien. Indien deze informatie een redelijke mate van betrouwbaarheid heeft, kunnen latere teleurstellingen, als de oorspronkelijke verwachtingen niet blijken uit te komen, worden beperkt. Bovendien zou van deze informatie een zekere sturing kunnen uitgaan in de richting van een betere aansluiting tussen de uitstroom uit de diverse geledingen van het onderwijs en de moge1ijkheden op de arbeidsmarkt.

Een vraagstuk is welke informatie over de arbeidsmarkt nu precies moet worden verschaft om aan een verantwoorde studiekeuze en een optimale aansluiting tussen vraag en aanbod op de arbeidsmarkt bij te dragen. In de Verenigde Staten wordt sinds enkele decennia door het Bureau of Labor Statistics van het U.S. Department of Labor een handboek samengesteld met actuele informatie over ongeveer 200 beroepen $^{2)}$. De verschafte gegevens betreffen de inhoud van het werk, de arbeidsomstandigheden, de arbeidsvoorwaarden, de vereiste opleiding, de werkgelegenheid en de werkgelegenheidsvooruitzichten. Deze gegevens worden op systematische wijze up to date gehouden. Recente informatie wordt in supplementen verwerkt en elke twee jaar wordt een nieuwe versie van het handboek uitgebracht.

1) David A. Kodde, Microeconomic analysis of demand for education, proefschrift Erasmus Universiteit Rotterdam, 1985.

2) U.S. Department of Labor, Bureau of Labor Statistics, Occupational Outlook Handbook, Washington. 
De vermelde werkgelegenheidsvooruitzichten zijn gebaseerd op gedetailleerde prognoses over een periode van ongeveer tien jaar. De prognoses van de werkgelegenheid zijn gedifferentieerd naar bedrijfstak en beroep, volgens een zeer gedetailleerde indeling. Er worden drie alternatieve ontwikkelingen onderscheiden: een lage, een gemiddelde of een hoge economische groei. E1ke twee jaar worden de prognoses opnieuw opgesteld en gepubliceerd. De kwantitatieve gegevens worden vervolgens op een indicatieve manier verwerkt in de nieuwe versie van het handboek.

Het antrekkelijke van deze benadering is dat de kwalitatieve informatie over de werkgelegenheid (de inhoud van het werk, de arbeidsomstandigheden $e_{\bullet} d_{\bullet}$ ) en de kwantitatieve informatie over de omvang en de groei van de werkgelegenheid steeds beschikbaar zijn op representatieve basis en aan de hand van recente inzichten, en dat beide soorten gegevens volledig op elkaar zijn afgestemd. Een dergelijke situatie zou ook voor Nederland op den duur moeten worden bereikt. Zoals in de inleiding is gesteld beperkt het onderhavige project zich vooralsnog tot het ontwikkelen van een systeem dat de vereiste kwantitatieve gegevens genereert.

Ten aanzien van de weergave van de beroepengegevens in de vorm van een handboek kan men zich afvragen of dit wel de doelmatigste opzet is. Moderne informatietechnieken laten het immers toe grote aantallen gegevens via gebruiksvriendelijke methoden voor besluitvormingsprocessen toegankelijk te maken. Momenteel wordt in Nederland een dergelijk systeem voor de school- en beroepskeuze ontwikkeld: I SEE (Information System on Employment and Education). Dit project beoogt de ontwikkeling van een geautomatiseerd informatiesysteem over opleidingen en beroepen. Het beperkt zich vooralsnog tot studies en beroepen op het $W_{.}$O. niveau en richt zich op VWo-leerlingen die uit een veelheid van studies er een moeten kiezen ${ }^{3)}$. Later zal dit systeem worden uitgebreid met stu-

3) H.M. Pere, Arbeidsmarktvoorlichting, een voorstel voor interdisciplinaire opbouw, Centrum voor Beleidsanalyse en Advies, Nijmegen, mei $1986, \mathrm{b1z} .4$. 
dies en beroepen voor de andere opleidingsniveaus. Het I SEE-project is een gezamenlijk project van de Ministeries van Onderwijs en Wetenschappen, Sociale Zaken en Werkgelegenheid, Economische Zaken en Landbouw en Visserij. De uitvoering berust bij het Centrum voor Beleidsanalyse en Advies te Nijmegen. Omdat de resultaten van dit project waarschijnlijk een grote rol gaan spelen bij de toekomstige vormgeving van het school- en beroepskeuzeproces is het doelmatig om dit project als referentiepunt te hanteren voor de vaststelling van de aard van de kwantitatieve gegevens die het arbeidsmarkt-informatiesysteem moet opleveren.

In een rapport dat in het kader van het I SEE-project is samengesteld worden een tiental arbeidsmarkt-indicatoren genoemd die van belang lijken voor een goede onderbouwing van de beroepskeuze c.q. het beroepskeuze-advies ${ }^{4}$.

1. de ontwikkeling van de omvang van het beroepsdomein;

2. het aandeel van het aantal werkenden binnen het domein in de totale beroepsbevolking;

3. het aandeel van verschillende categorieën beroepsoefenaren in het desbetreffende domein;

4. het opleidingsniveau en de opleidingsichting van beroepsbeoefenaren;

5. de mate van crisisgevoeligheid van het beroepsdomein;

6. de leeftijdsopbouw van de beroepsbeoefenaars;

7. de te verwachten ontwikkeling van het domein;

8. de te verwachten toestroom van arbeidskrachten naar het domein;

9. mogelijke regionale verschillen in werkgelegenheid;

4) H.M. Pere, op.cit., blz. 31 en 32. 
10. de te verwachten discrepantie tussen vraag en aanbod in het beroepsdomein ${ }^{5)}$.

Deze lijst is niet meer dan een voorzet voor een discussie en verder onderzoek. Nader moet worden bezien met welke elementen de 1ijst zou moeten worden aangevuld dan wel ingekrompen en op welke wijze de gegevens aan de gebruikers dienen te worden gepresenteerd. Hiervoor lijkt een onderzoek onder de potentiële gebruikers van de desbetreffende gegevens nodig ${ }^{6}$ ). Ook zal moeten worden vastgesteld of het mogelijk is de gewenste gegevens te verzamelen en hun ontwikkeling naar de toekomst door te trekken.

De eerste - experimentele - versie van het te ontwikkelen informatiesysteem zal een beperking inhouden ten opzichte van de genoemde 1ijst. Het systeem zal zich vooralsnog beperken tot de indicatoren die onder de punten 1 en 7 zijn genoemd (de ontwikkeling van de werkgelegenheid), terwij1 de afbakening van de beroeps- of functiedomeinen globaal zal zijn. Gedacht wordt aan een onderscheid naar enkele tientallen beroeps- of functiecategorieën. De overige punten zullen eerst aan de orde komen in het begeleidende programma van onderzoek (de "tweede lijn"), waarna zal worden getracht ze op te nemen in het informatiesysteem. Een aspect dat bijvoorbeeld eerst nader onderzoek vereist alvorens het op te nemen in het informatiesysteem, is het optreden van substitutie- en verdringingsprocessen naar respectievelijk opleidingsrichting en opleidingsniveau.

5) De discrepanties naar opleiding zouden kunnen worden uitgedrukt in werkloosheidsduren. Zie bijv. Department of Education and Science en Department of Employment, Graduates and Jobs, Some Guidance for Young People Considering a Degree, Londen, juni 1984. Vooralsnog zal een en ander echter beperkt blijven tot werkloosheidspercentages.

6) Bijvoorbeeld in de vorm van experimenten met concrete keuzesituaties, zoals in de pilot-fase van het I SEE-project is voorzien. 


\section{DE RELATIE ONDERWIJS - ARBEIDSMARKT IN SCHEMA}

Voor de ontwikkeling van het informatiesysteem onderwijs-arbeidsmarkt is het van belang dat een beeld wordt gevormd van de wijze waarop het onderwijs en de arbeidsmarkt aan elkaar zijn gerelateerd. Dit beeld is nodig als referentiekader voor de ontwikkeling en verdere uitbouw van de modellen en rekenschema's die de kern zullen vormen van het informatiesysteem. Helaas is een dergelijk beeld niet pasklaar voorhanden. Daarvoor is de relatie onderwijs-arbeidsmarkt te complex en lopen de opinies over de mogelijke samenhangen te ver uiteen.

Het zou hier te ver voeren om aan de hand van een uitgebreide analyse van de beschikbare literatuur het bovenbedoelde beeld alsnog te schetsen. Daarom zal worden volstaan met het geven van een globale en noodgedwongen subjectieve impressie, welke voornamelijk aan economische noties zal zijn ontleend. Deze impressie zal worden gegoten in de vorm van een schema. Aan dit schema (zie b1z. 10) moet uiteraard geen absolute betekenis worden toegekend; het heeft slechts heuristische waarde en is alleen bedoeld als praktisch hulpmiddel om enkele grootheden, die a priori relevant lijken, te benoemen en in een onderling verband te plaatsen. Later zou het schema op basis van nieuwe inzichten kunnen worden bijgesteld en uitgewerkt.

In het schema geeft elk blok een bepaalde grootheid aan en de pijlen geven de verbanden tussen de onderscheiden grootheden weer, alsmede de richting van deze relaties. De grootheden die in belangrijke mate door factoren buiten het schema worden bepaald (dus exogeen zijn), zijn dubbel omlijnd. Een aanzienlijke vereenvoudiging is, dat geabstraheerd wordt van de tijdsdimensie: sommige relaties hebben betrekking op (toekomst)verwachtingen, terwijl andere relaties pas met vertraging in de tijd doorwerken. Het schema is uit verschillende delen opgebouwd. Om de dynamiek in de relatie tussen het onderwijs en de arbeidsmarkt goed te kunnen weergeven is aan het arbeidsmarktdeel van het schema een 


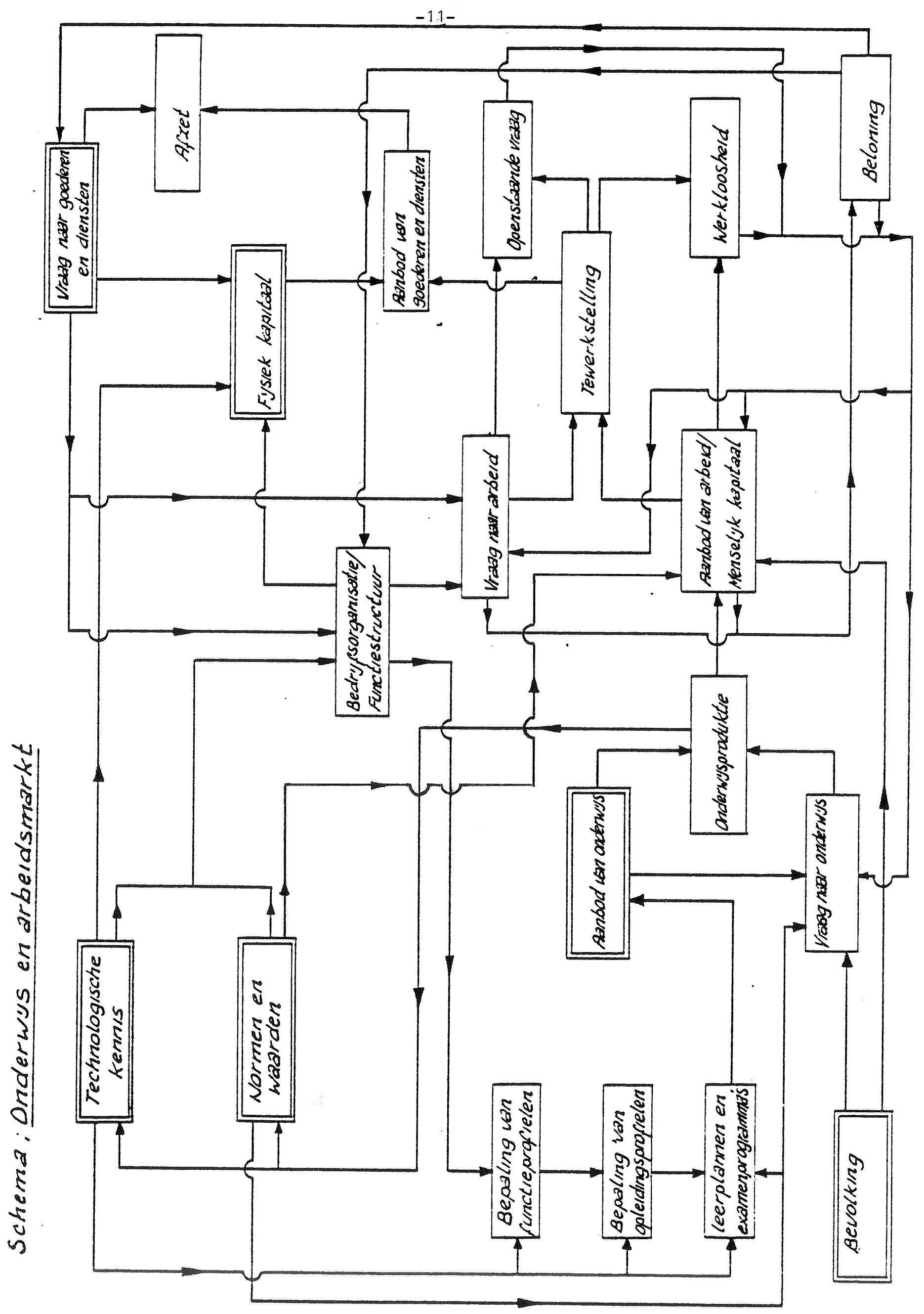


economisch deel toegevoegd en is het deel dat de onderwijsmarkt beschrijft uitgebreid met de ontwikkeling van leerprogramma's.

Het schema is als volgt ingedeeld. Linksboven staan twee belangrijke niet-economische factoren die langs allerlei wegen invloed uitoefenen op de relatie tussen het onderwijs en de arbeidsmarkt: de stand van de technologische kennis en het stelsel van normen en waarden. Rechtsboven in het schema is de produktie en afzet van goederen en diensten weergegeven. Hiervan gaat vanzelfsprekend een belangrijke invloed uit op de vraagzijde van de arbeidsmarkt. De arbeidsmarkt is in het rechterbenedendeel van het schema weergegeven. Het 1 inkerbenedendeel heeft betrekking op de onderwijsmarkt, welke een belangrijke invloed uitoefent op de anbodzijde van de arbeidsmarkt.

Het onderwijs, als kweekvijver van kennis en vaardigheden alsmede de houding en opvattingen van mensen, levert geen homogeen produkt af. Kennis en vaardigheden kunnen zowel qua niveau als richting verschillen. De op de arbeidsmarkt vereiste kwalificaties zijn eveneens naar niveau en richting gedifferentieerd. Hoewel het hieruit voortvloeiende coördinatieprobleem een belangrijk element vormt van de onderlinge afstemming van het onderwijs en de arbeidsmarkt, zijn de mogelijke differentiaties binnen het onderwijs - uit oogpunt van eenvoud - niet expliciet aangegeven in het schema.

In het schema is het onderwijs opgevat als een markt waar onderwijs wordt aangeboden en gevraagd. Het aanbod van onderwijs, dat wil zeggen de beschikbare onderwijscapaciteit, vormt op de korte termijn een gegeven. De omvang en samenstelling van het aangeboden onderwijs wordt, binnen het kader van de daarvoor bestaande regelingen, bepaald door de publieke en private onderwijsinstanties (buiten het schema). De inhoud en de kwaliteit van het aan- 
geboden onderwijs worden in belangrijke mate bepaald door de ontwikkelde leerplannen en examenprogramma's (we1 in het schema).

De vraag naar onderwijs hangt direct samen met de omvang en samenstelling van de bevolking (naar leeftijd, geslacht, intelligentie, sociale groep e.d.). Bij de onderwijskeuze zal men zich behalve door de normen en waarden in de matschappij ook laten leiden door de (verwachte) beloning na voltooiing van de opleiding, het sociaal-economische milieu van de ouders en de (verwachte) kansen op het vinden van een baan (zie de pijlen van beloning, openstaande vraag en werkloosheid naar de vraag naar onderwijs).

Het aanbod van onderwijs en de vraag naar onderwijs bepalen samen de feitelijke onderwijsproduktie. Via de cultuuroverdracht binnen het onderwijs heeft het onderwijs een belangrijke invloed op de normen en waarden in de matschappij (zie de pij1 van onderwijsproduktie naar normen en waarden). De onderwijsproduktie (incl. onderzoek) vormt ook een belangrijke voedingsbron voor de ontwikkeling en verspreiding van de technologische kennis.

Zowel de matschappelijke normen en waarden als de technologische kennis zijn zelf weer van invloed op het onderwijs. Zoals opgemerkt spelen normen en waarden een rol bij de keuze van het niveau en de richting van het te volgen onderwijs. De technologische kennis, met name de verkregen onderwijskundige inzichten en de ontwikkelde methoden van leerplanontwikkeling, spelen een rol in het ontwikkelingswerk op het terrein van het onderwijs. In het schema is het ontwikkelingswerk ten aanzien van het (beroeps)onderwijs in drie stappen uiteengelegd, respectievelijk de bepaling van beroeps- of functieprofielen, opleidingsprofielen en leerplannen. Bij elk van deze stappen wordt geput uit bestaande (onderwijskundige) kennis. De bepaling van beroeps- en functieprofielen vindt mede aan de hand van gegevens (of percepties) 
over de beroepspraktijk binnen bedrijfsorganisaties plaats (zie de pijl van bedrijfsorganisaties naar bepaling van functieprofielen). Het onderwijs vervult echter meer functies dan het geven van een goede voorbereiding op het beroepsleven. Bij de ontwikkeling van leerprogramma's zullen normen en waarden een rol spelen ten aanzien van de invulling en afweging van de onderwijskundige elementen die niet rechtstreeks betrekking hebben op het latere beroepsleven.

Het onderwijs is gekoppeld aan de aanbodzijde van de arbeidsmarkt. De (gecumuleerde) onderwijsproduktie bepaalt - samen met de omvang en samenstelling van de bevolking, de opvattingen in de matschappij over het al dan niet verrichten van arbeid, de loonvoeten van de verschillende soorten arbeid en de kansen op het vinden van een baan - de omvang en samenstelling van het menselijk kapitaal dat zich a anbiedt op de arbeidsmarkt.

De vraagzijde van de arbeidsmarkt is verbonden met het systeem van economische voortbrenging. De vraag naar de produktiefactoren kapitaal en arbeid wordt in belangrijke mate bepaald door de verwachtingen over de toekomstige vraag naar goederen en diensten welke met beide produktiefactoren kunnen worden voortgebracht. De bedrijfsorganisatie bepaalt de verhoudingen waarin de produktiefactoren zullen worden ingezet. Hierbij gaat het om enerzijds de verhouding tussen kapitaal en arbeid en anderzijds de verhouding tussen de verschillende soorten arbeid.

De bedrijfsorganisatie is niet constant, maar kan op de lange termijn veranderen. Er zijn keuzemogelijkheden welke worden bepaald door de omvang van de vraag naar goederen en diensten ( $c . q$. de bedrijfsgrootte), het soort produkt dat wordt gevraagd en de stand van de technologie. De technologie is deels belichaamd in de in te zetten kapitaalinstallaties. De feitelijke keuze die men uit de beschikbare mogelijkheden makt, is gebaseerd op de huidige en de verwachte beloning van kapitaal en de verschillende soorten arbeid, alsmede op de opvattingen die men heeft over een 
doelmatige organisatie (zie voor het laatste de pij1 van normen en waarden naar bedrijfsorganisatie). Bij de daadwerkelijke werving van arbeidskrachten zal men inspelen op de kansen om de vereiste soorten arbeidskrachten op de desbetreffende deelmarkten te vinden. Hierdoor kan verdringing van lager door hoger geschoolde arbeidskrachten optreden, zonder dat de functiestructuur substantieel verandert.

Vraag en aanbod op de arbeidsmarkt bepalen samen de (gerealiseerde) tewerkstelling van arbeidskrachten. De mate waarin de vraag naar arbeid niet wordt bevredigd geeft de openstaande vraag weer. Het aanbod dat geen emplooi vindt vormt de werkloosheid.

De omvang en de samenstelling van de beschikbare kapitaalgoederenvoorraad en de tewerkgestelde arbeid bepalen het aanbod van goederen en diensten in de economie. Naar analogie van de arbeidsmarkt, vormt de (gerealiseerde) afzet van goederen en diensten het resultaat van vraag en aanbod.

Tenslotte loopt er nog een verbindingslijn van de arbeidsmarkt naar de markt van goederen en diensten via de beloning, welke immers een deel van de koopkrachtige vraag in de economie bepaalt.

In het besproken schema is de relatie tussen het onderwijs en de arbeidsmarkt, zoals opgemerkt, op globale wijze weergegeven. Hoewel het schema door de vele, soms langs grillige paden verlopende, terugkoppelingen al behoorlijk ingewikkeld mag lijken, is de werkelijkheid nog aanzienlijk complexer. Hier komt bij dat het onderwijs niet homogeen is, zoals het schema wellicht zou suggereren. Er is een veelkleurig palet aan onderwijsmogelijkheden dat allerlei differentiaties mogelijk maakt naar niveau, opleidingsrichting en specialisatie. De via verschillende routes binnen het onderwijssysteem genoten vorming, opgedane kennis en verkregen vaardigheden leveren een uiterst geschakeerd beeld op van het aanwezige menselijke kapitaal dat emplooi zoekt of heeft gevonden 
op de arbeidsmarkt. Aan de vraagzijde van de arbeidsmarkt is het beeld niet minder veelkleurig. Het heterogene pakket van voortgebrachte goederen en diensten, de onderscheiden technologische mogelijkheden en de op verschillende principes berustende organisatiestructuren gaan gepaard met een veelheid aan beroepen en functies, die onderling sterk uiteenlopende eisen stellen aan de niveaus en soorten van kennis en vaardigheden van individuen die deze posities zouden moeten vervullen of reeds vervullen. Het streven naar een betere aansluiting tussen onderwijs en arbeidsmarkt vraagt om de oplossing van een enorm coördinatieprobleem, dat in de loop van de tijd eerder groter dan kleiner lijkt te worden. 


\section{EEN EENVOUDIG MODEL VAN DE WERKGELEGENHEID NAAR BEROEP}

In de inleiding is uiteengezet dat bij de ontwikkeling van het informatiesysteem van de arbeidsmarkt twee lijnen zullen worden gevolgd. Deze paragraaf betreft de eerste lijn: het ontwikkelen van een eenvoudig systeem waarmee de werkgelegenheid kan worden voorspeld, gedifferentieerd naar beroeps- en functiecategorieën. In de volgende paragraaf zal de tweede lijn, het bij dit systeem aansluitende programma van onderzoek, worden uitgewerkt.

Het volgens de eerste lijn op te zetten systeem zal in relatief korte tijd moeten kunnen worden ontwikkeld. Dit kan worden bereikt door het systeem te beperken tot een aantal modellen die volgens de beproefde "top down"-benadering an elkaar zijn gekoppeld. Deze benadering houdt in dat enkele modellen, die elk een bepaald facet van het systeem op een verschillend aggregatieniveau beschrijven, volgens een bepaalde hiërarchische rangschikking met elkaar worden verbonden. Deze modellen of modeluitkomsten zullen reeds beschikbaar moeten zijn of met behulp van direct beschikbare statistische gegevens in korte tijd kunnen worden verkregen. In bijgaand schema wordt een voorstel gedaan voor een dergelijk eenvoudig systeem.

Het linkerdeel van het schema geeft de opeenvolgende facetten (stappen) van het werkgelegenheid-informatiesysteem weer. Het rechterdeel heeft betrekking op de econometrische modellen die kunnen worden toegepast om de desbetreffende stap te maken. Een belangrijk uitgangspunt wordt gevormd door de veronderstellingen over het toekomstig verloop van exogene grootheden als bevolking, wereldhandel, overheidsuitgaven en arbeidsduur. Hierbij zou kunnen worden aangesloten bij de veronderstellingen welke worden gemaakt bij de lange termijn voorspellingen van het CPB. Om te beklemtonen dat prognoses slechts geldig zijn onder bepaalde veronderstellingen, zouden bij het werkgelegenheid-informatiesysteem verschillende varianten ("scenario's") kunnen worden opgesteld. Hierdoor zou bovendien een indruk kunnen worden ver- 
SCHEMA: WERKGELEGENHEID INFORMATIESYSTEEM

Systeem

Modeltype

Veronderstellingen

(exogenen), wo

- bevolking

- wereldhandel

- overheid

- arbeidsduur

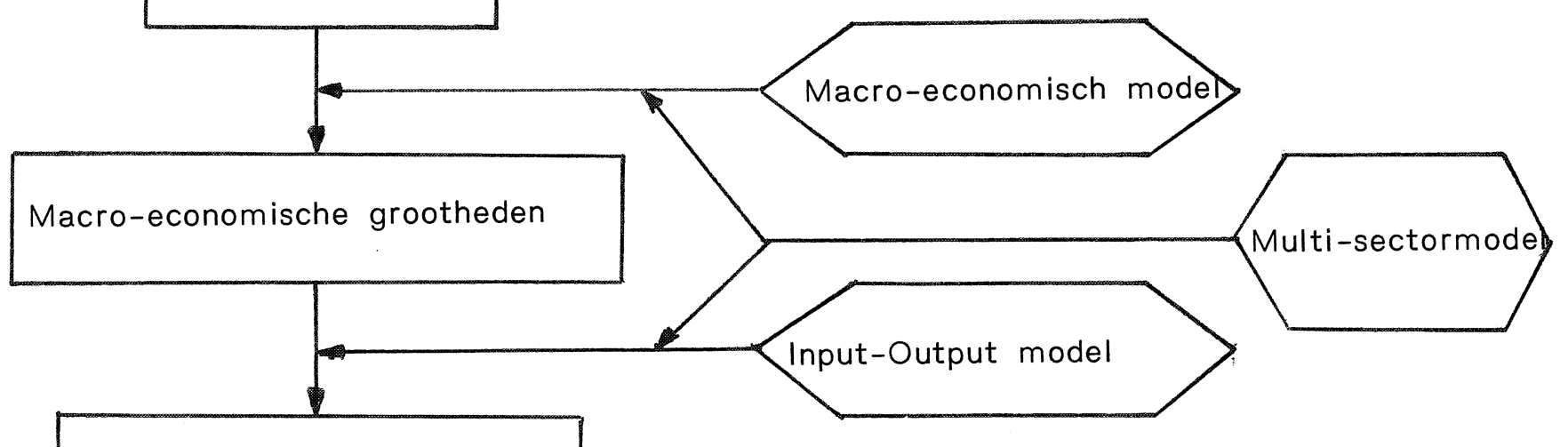

Bedrijfstak grootheden

w.o. werkgelegenheid

Verdeelmodel

Werkgelegenheid naar branche

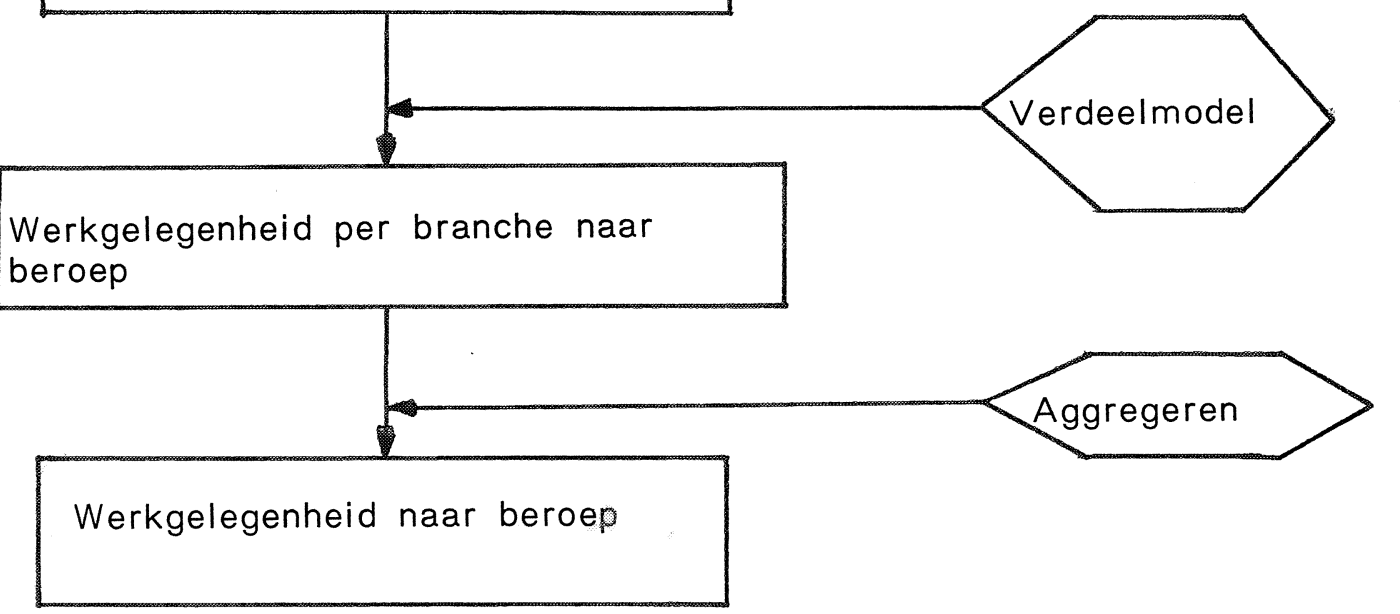


schaft van de gevoeligheid van de prognose-uitkomsten voor de gemaakte veronderstellingen. In dit stadium van ontwikkeling van het werkgelegenheid-informatiesysteem lijkt het verstandig de prognoses te beperken tot een termijn van vijf jaar.

In het schema is aangegeven dat de veronderstellingen vooral dienen als uitgangspunt voor de prognoses van de macro-economische ontwikkeling. Door koppeling van de macro-economische prognoses a an een input-output model kunnen prognoses worden verkregen van de produktie en de werkgelegenheid naar bedrijfstak. Indien over (de uitkomsten van) een multi-sectormodel kan worden beschikt, worden beide hierboven genoemde stappen in feite in elkaar geschoven.

Met behulp van branches-verdeelmodellen kan de geprognosticeerde werkgelegenheid per bedrijfstak naar de onderliggende branches worden verdeeld. Toepassing van beroepen-verdeelmodellen op de werkgelegenheid per branche levert de werkgelegenheid naar beroep op. Tenslotte wordt door aggregatie over de branches de totale werkgelegenheid in elk beroep gevonden.

Hier geschetste werkwijze is relatief eenvoudig en is reeds eerder in de praktijk beproefd ${ }^{7)}$. Wel zal de differentiatie naar branches en beroepen veel groter zijn. Gedacht wordt aan een differentiatie van de werkgelegenheid naar enkele tientallen, en zo mogelijk naar 60 tot 80 beroepen. Teneinde zoveel mogelijk gebruik te maken van reeds aanwezige kennis zal worden getracht de prognoses van de macro-economische en de bedrijfstak ontwikkelingen te ontlenen a an het CPB. De onderzoekwerkzaamheden kunnen

7) Nederlands Economisch Instituut, Een verkenning van de arbeidsmarkt naar beroep en opleiding tot 1990, OSA-Werkdokument nr. 17, januari 1986. 
zich dan beperken tot de ontwikkeling van de branches- en de beroepenverdeelmodellen. Veel aandacht zal hierbij moeten worden besteed aan de meest doelmatige ${ }^{8)}$ afbakening van de beroependomeinen en de stabiliteit van de verdeelparameters. Verder zal de behandeling van het aspect arbeidstijd (deeltijd e.d.) nog intensieve aandacht behoeven.

Teneinde de ontwikkelingstijd van de eerste versie van het werkgelegenheid-informatiesysteem zo kort mogelijk te houden, zal deze versie van het systeem uitsluitend worden gebaseerd op bronnen als de nationale rekeningen en de arbeidskrachtentellingen. In het kader van de tweede (programma) lijn zullen uiteraard wel nieuwe mogelijkheden voor datavergaring worden geëxploreerd.

Tenslotte moet over de opzet van hier bedoelde versie van het werkgelegenheid-informatiesysteem worden opgemerkt, dat deze zodanig zal zijn dat het mogelijk is eind 1987 de eerste - voorlopige - prognoseresultaten op te leveren. Deze resultaten zullen worden vervat in een prototype van een in de toekomst tweejaarlijks samen te stellen publicatie.

Benadrukt moet worden dat het hier gaat om een voorlopige versie van het werkgelegenheid-informatiesysteem. De uitvoering van de activiteiten volgens de tweede programmalijn zal leiden tot bijstelling van het systeem zoals het in eerste versie is ontwikkeld. Ook de nieuwe versie zal overigens geen definitieve zijn. Het systeem zal steeds op basis van nieuwe wensen en mogelijkheden verder moeten worden ontwikkeld. Er zal echter naar worden

8) "Doelmatig" moet hier worden bezien in relatie tot de aansluiting tussen onderwijs en arbeidsmarkt en de school- en beroepskeuzeproblematiek. 
gestreefd ruimschoots binnen de voor het project beschikbaar gestelde vijf jaar een versie te ontwikkelen die voldoende bruikbaar mag worden geacht voor het beantwoorden van vragen op het terrein van de school- en beroepskeuze.

De eerste versie van het werkgelegenheid-informatiesysteem beperkt zich tot de vraagzijde van de arbeidsmarkt. De ontwikkeling van de werkgelegenheid in een bepaalde beroepsgroep wordt in dat systeem bepaalt door een drietal factoren:

- de ontwikkeling van de afzet in de bedrijfstakken of branches waarin de desbetreffende arbeidskrachten werkzaam zijn;

- de technologische en organisatorische veranderingen in de produktieprocessen binnen deze bedrijfstakken of branches;

- de verandering van de arbeidstijd.

De verdere ontwikkeling van het werkgelegenheid-informatiesysteem zou zich onder meer op de tweede factor kunnen richten. Het systeem zou kunnen worden verrijkt met (1) indicatoren die een beeld geven van de mate waarin technologisch diffusieprocessen in bedrijfstakken of branches zijn voortgeschreden en (2) de betekenis van deze processen voor de omvang en de beroepen- en opleidingenstructuur van de werkgelegenheid in die bedrijfstakken of branches.

Een volgend aspect dat in het systeem moet worden ingebracht betreft de verdeling van beroepen naar vereiste opleidingen. Hiervoor is een nadere analyse van substitutie- en verdringingsprocessen nodig en zullen er modellen moeten worden ontwikkeld die deze processen beschrijven.

Voor het school- en beroepskeuzevraagstuk is het van belang te weten wat de kansen en mogelijkheden van de toekomstige verlaters van een bepaalde opleiding zijn op de arbeidsmarkt. Een verdere uitbreiding van het informatiesysteem zou er daarom in kunnen bestaan de werkgelegenheidsinformatie toe te spitsen op deze groep. Hiervoor is het nodig ook a anbodfactoren in het systeem op te nemen. Met name zou rekening moeten worden gehouden met: 
1. de uittrede van arbeidskrachten uit de beroepsbevolking, het zgn. natuurlijke verloop;

2. de netto-uitstroom van arbeidskrachten naar een andere beroepsgroep;

3. de netto herintrede van arbeidskrachten uit de niet-werkende bevolking:

4. de door- en uitstroom van leerlingen en studenten in het onderwijs.

Door de hierboven geschetste verdere ontwikkeling van het werkge-

legenheid-informatiesysteem, zal het systeem evolueren naar een informatiesysteem onderwijs en arbeidsmarkt. 


\section{HET ONDERZOEKPROGRAMMA}

In het volgende zal het bij de ontwikkeling van het informatiesysteem aansluitende onderzoeksprogramma worden aangegeven.

Het programma is in drie delen gesplitst. Deel A heeft betrekking op onderzoek dat door het ROA zal worden uitgevoerd, deel B op het lopende onderzoek van de economische faculteit en deel $\mathrm{C}$ betreft het onderzoek dat op initiatief van het ROA bij de economische faculteit zal worden aangekaart. Het onder $B$ en $C$ genoemde onderzoek heeft alleen betrekking op onderzoek dat op langere termijn resultaten zou kunnen opleveren die van belang zijn voor de totstandkoming van het informatiesysteem onderwijs-arbeidsmarkt.

Het programma dekt een periode van ongeveer twee jaar. Het programma zal tussentijds aan de hand van de voortgang van het onderzoek en de ontwikkeling van nieuwe plannen worden bijgesteld. Het jaar waarin het desbetreffende onder A genoemde onderzoek volgens planning zal starten, zal bij elk project worden aangegeven.

\section{A. ROA-projecten}

87.1. Afbakening van beroeps- en functiedomeinen ten behoeve van de eerste versie van het werkgelegenheid-informatiesysteem. Gestreefd wordt naar een aantal van enkele tientallen, zo mogelijk 60 tot 80 domeinen. (Daarbij zal de mogelijkheid van verdere differentiatie worden onderzocht).

Een belangrijk criterium voor de afbakening van deze domeinen wordt gevormd door de opleidingstructuren van de beroepen.

87.2. Analyse van het aantal gewerkte uren en de verwerking van de resultaten hiervan in de eerste versie van het werkgelegenheid-informatiesysteem. 
87.3. Ontwikkeling en schatting van de branches- en de beroepenverdeelmodellen ten behoeve van de eerste versie van het werkgelegenheid-informatiesysteem.

87.4. Opstelling van toekomstprojecties over een periode van vijf jaar met behulp van de eerste versie van het werkgelegenheid-informatiesysteem.

87.5. Analyse van de karakteristieken van de werkgelegenheidsontwikkeling van de onderscheiden beroeps- en functiedomeinen. Het gaat hier om karakteristieken zoals omschreven in paragraaf 2: Arbeidsmarktgegevens voor schoo1- en beroepskeuze.

87.6. Inventarisatie van instanties die prognoses opstellen met betrekking tot delen van de arbeidsmarkt. Het nagaan van de mogelijkheden om deze prognoses te integreren in de prognosemethodiek die door het ROA wordt ontwikkeld. Het maken van voorlopige afspraken met instanties warmee een vruchtbare samenwerking mogelijk lijkt.

87.7. Inventarisatie van instanties die informatie hebben over technologische ontwikkelingen en nieuwe organisatiepatronen en over hun implicaties voor de omvang en de beroepen- en opleidingenstructuren van de werkgelegenheid. Nagaan van de mogelijkheden om deze informatie te verwerken in de prognosemethodiek van het ROA. Maken van voorlopige afspraken met instanties waarmee een vruchtbare samenwerking mogelijk $1 i j k t$.

88.1. Evaluatie van de uitkomsten van de eerste versie van het werkgelegenheid-informatiesysteem. Opsporen van de belangrijkste bronnen van voorspelfouten.

88.2. Inventarisatie en exploratie van anvullende of nieuw op te zetten data-bestanden ten behoeve van de verbetering en 
verdere uitbouw van het werkgelegenheid-informatiesysteem. Voorlopige gedachten gaan uit naar gegevens over lonen, arbeidstijd, vacatures, leeftijden, beroeps- en branchemigratie, de bestemming van onderwijsverlaters op de arbeidsmarkt, meer gedetailleerde beroeps- en functiedomeinen, alsmede meer actuele informatie over de werkgelegenheid naar beroep.

88.3. Internationale conferentie van experts over de in de diverse landen toegepaste prognosemethodieken op het terrein van de aansluitingsproblematiek onderwijs-arbeidsmarkt. Intensieve discussie over zowel de toegepaste methoden als de plannen voor verdere uitbouw en verbetering van deze methoden. Samenstelling van een gezamenlijke publicatie.

88.4. Onderzoek naar de ontwikkeling van opleidingseisen van beroepen en functies, in het bijzonder naar de substitutieen verdringingsproblematiek.

88.5. Ontwikkeling van een plan voor verbetering en verdere uitbouw van het informatiesysteem.

B. Lopende Facultaire projecten waarmee raakvlakken bestaan

1. Ten behoeve van de programmacommissie Technologie en Economie wordt een geĩntegreerde analyse op micro-, meso- en macroniveau uitgevoerd naar de effecten van technologische ontwikk lingen op de werkgelegenheid. Bij dit onderzoek worden in het bijzonder de volgende vragen behandeld:

- Hoe heeft de werkgelegenheid zich in Nederland ontwikkeld op het niveau van bedrijfsklassen en beroepsgroepen?

- Hoe hebben de omvang en samenstelling van de produktie zich in Nederland ontwikkeld? 
- Welke technologische veranderingen zijn voor deze ontwikkelingen van betekenis geweest?

- Welke kwantitatieve samenhangen kunnen uit het voorgaande worden gedestilleerd en in welke mate bieden deze aanknopingspunten voor het afleiden van prognoses?

2. In het kader van de voorwaardelijke financiering wordt een programma uitgevoerd van onderzoek naar arbeidsmarkt en arbeidsorganisaties. Het centrale thema van dit onderzoekprogramma betreft de aansluiting tussen vraag en aanbod van arbeid, zowel in kwantitatief als kwalitatief opzicht. Het programma omvat de volgende deelprojecten:

1. arbeidsmarkt;

2. a rbeidsorganisaties;

3. arbeid en technologie;

4. arbeid en publieke sector.

Binnen het thema arbeidsmarkt zijn met name de volgende projecten van belang:

- De vraag naar arbeid. Dit project beoogt een bijdrage te leveren aan de verklaring van de vraag naar arbeid op ondernemingsniveau en op bedrijfsniveau. Bij dit project zal de vraag worden gespecificeerd naar meerdere beroepsgroepen;

- Een meer-sectoren model voor de arbeidsmarkt in Nederland. Bij dit onderzoek wordt voor diverse delen van dit model samengewerkt met de Rijksuniversiteit Groningen en de Technische Universiteit Twente. De RL zal het arbeidsmarktblok van het model ontwikkelen. In dit model zal de vraag naar arbeid worden gespecificeerd naar meerdere beroepsgroepen.

Binnen het thema arbeidsorganisaties kunnen de volgende projecten worden genoemd:

- Werkgelegenheid bij een veranderde bedrijfsomvang. In dit project wordt nagegaan wat de gevolgen zijn van heterogeniteit van arbeid en kapitaal binnen éen onderneming voor het Werkgelegenheid bij een veranderende bedrijfsomvang. In dit verloop van de werkgelegenheid bij deze onderneming in een 
veranderende omgeving wat betreft groei, conjunctuurcycli e.d.

- De ontwikkeling van arbeid in organisaties. Bij dit project is de aandacht gericht op de interne arbeidsmarkt van organisaties. Zowel kwantitatieve als kwalitatieve ontwikkelingen met betrekking tot de factor arbeid zullen centraal staan.

3. Het thema arbeid en technologie is later uitgewerkt tot een zelfstandig programma, Technologische Ontwikkeling en Innovatie, dat eveneens wordt uitgevoerd in het kader van de voorwaardelijke financiering. Uit dit programma kunnen de volgende projecten van belang zijn voor het programma onderwijs en arbeidsmarkt ${ }^{9)}$ :

- Technologie, innovatie en werkgelegenheid in Europa. Dit project richt zich op de analyse van technologische ontwikkeling en arbeidsmobiliteit en de toename van werk binnen Europa. Speciale aandacht wordt besteed aan de werkgelegenheidseffecten van informatie technologieën.

- Technologie, organisatie-ontwerp en beleid. Dit onderzoek richt zich primair op de keuzeprocessen rond de invoering en het gebruik van informatietechnologieën.

- Diensten en technologische ontwikkeling. In dit onderzoek kunnen aspecten als produktiviteit, beroepsstructuur en opleidingsniveau an de orde komen.

9) Het programma Technologische Ontwikkeling en Innovatie omvat tevens enkele projecten die al zijn genoemd. Deze zullen hier niet worden herhaald. 


\section{Door ROA te initiëren facultaire projecten}

1. Onderzoek naar de betekenis van de aard en het tijdpatroon van de beschikbare arbeidsmarktinformatie voor de keuzen binnen het onderwijs en de allocatie op en de dynamiek van de arbeidsmarkt.

2. Onderzoek naar de betekenis van de genoten universitaire opleiding voor de positie op de arbeidsmarkt en de beroepsuitoefening. 
Personele samenstelling ROA

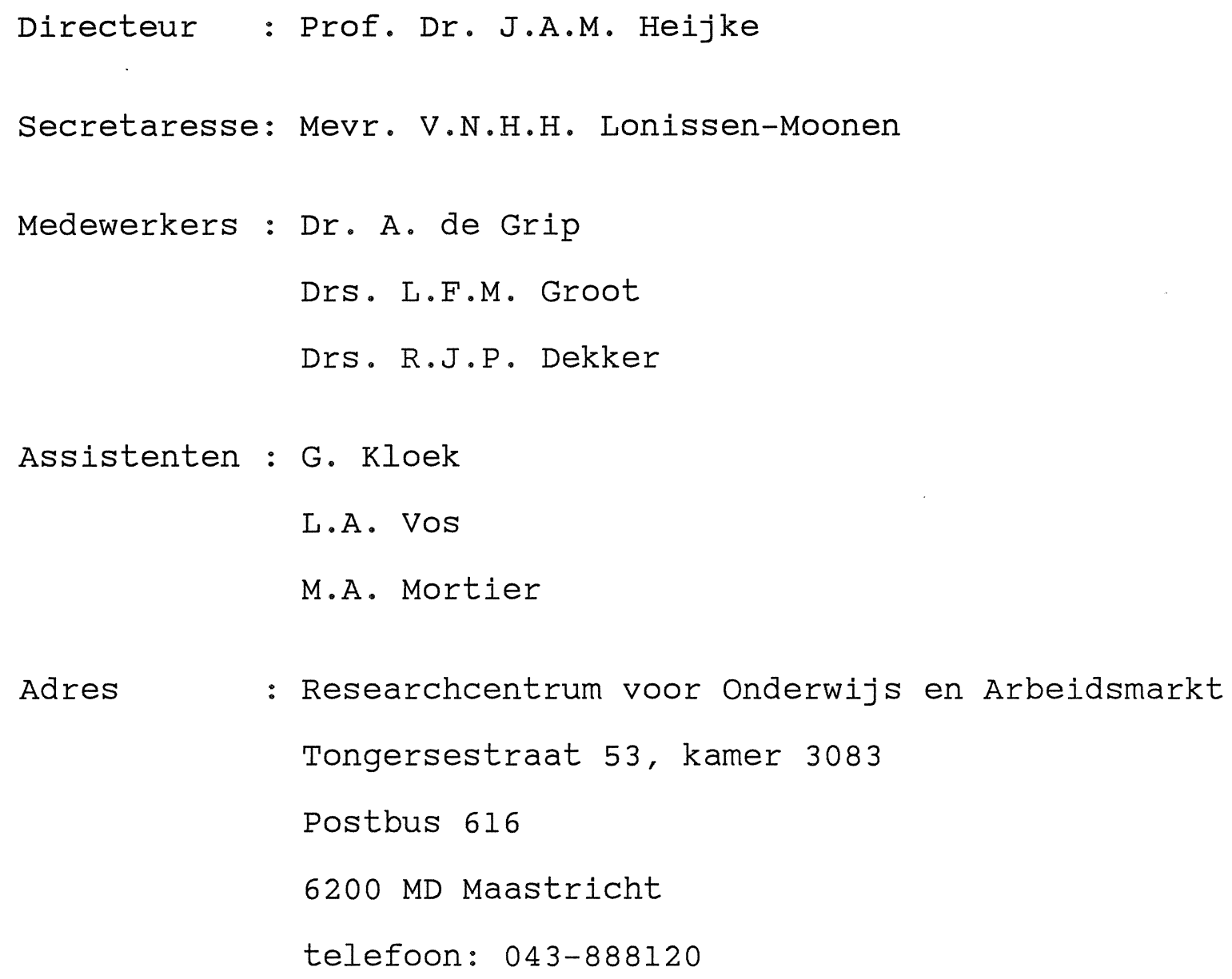

